\title{
PENGARUH STRATEGI PEMBELAJARAN DAN KEMAMPUAN APRESIASI SENI MUSIK TERHADAP HASIL BELAJAR SENI MUSIK
}

\author{
Elisa $^{1}$ dan Mukhtar ${ }^{2}$ \\ SMP Negeri Aceh Tamiang ${ }^{1}$ dan Universitas Negeri Medan ${ }^{2}$ \\ elisa@yahoo.com ${ }^{1}$
}

\begin{abstract}
Abstrak: Tujuan penelitian ini untuk: (1) mengetahui hasil belajar Seni Musik siswa yang diajar dengan strategi pembelajaran kontruktivisme dengan strategi pembelajaran langsung; (2) mengetahui hasil belajar Seni Musik antara siswa dengan tingkat kemampuan apresiasi seni musik tinggi lebih dengan kemampuan apresiasi seni musik rendah; dan (3) mengetahui interaksi antara strategi pembelajaran dan kemampuan apresiasi seni musik dalam mempengaruhi hasil belajar Seni Musik. Metode penelitian eksperimental-semu dengan desain faktorial 2x2. Teknik analisis deskriptif dengan statistik inferensial ANAVA dua jalur taraf signifikan $\alpha=0,05$ dilanjutkan dengan uji Scheffe. Hasil penelitian menunjukkan bahwa: (1) hasil belajar Seni Musik siswa yang diajar dengan strategi pembelajaran konstruktivisme lebih tinggi dibandingkan dengan strategi pembelajaran langsung F hitung 9,58 > F tabel 3,94; (2) hasil belajar Seni Musik siswa dengan kemampuan apresiasi seni musik tinggi lebih tinggi dari pada kemampuan apresiasi seni musik rendah $F$ hitung 25,48 > F tabel 3,94; dan (3) terdapat interaksi antara strategi pembelajaran dan kemampuan apresiasi seni musik dalam mempengaruhi hasil belajar Seni Musik F hitung 35,08 > F tabel 3,94.
\end{abstract}

Kata Kunci: strategi pembelajaran, kemampuan apresiasi, seni musik

Abstract: The purpose of this study was to: (1) determine learning outcomes Music Arts students who are taught by constructivism learning strategy with direct learning strategies; (2) determine the results of Art Music learning among students with the level of appreciation of the ability of high musical art more with the ability to lower the appreciation of the art of music; and (3) the interaction between learning strategy and the ability of art appreciation of music in affecting learning outcomes Music Arts. Quasi-experimental research methods with a $2 \times 2$ factorial design. Techniques descriptive inferential statistical analysis ANOVA two-lane significant level $\alpha=0.05$ followed by Scheffe test. The results showed that: (1) the learning outcomes of Music Arts students who are taught by constructivism learning strategy is higher than the direct learning strategies 9.58 F c t> F t 3.94; (2) Musical Arts learning outcomes of students with high musical art appreciation ability is higher than on the ability of low musical art appreciation $25.48 \mathrm{Fc}>\mathrm{Ft}$ 3.94; and (3) there is interaction between learning strategy and the ability of art appreciation of music in affecting learning outcomes Music Arts 35.08 F c > F t 3,94.

Keywords: learning strategies, the ability of appreciation, music

\section{PENDAHULUAN}

Muatan Seni Musik sebagaimana yang diamanatkan dalam Peraturan Pemerintah Republik Indonesia Nomor 19 tahun 2005 tentang Standar Nasional Pendidikan tidak hanya terdapat dalam satu mata pelajaran karena musik itu sendiri meliputi segala aspek kehidupan. Dalam mata pelajaran Seni Musik, aspek musik tidak dibahas secara tersendiri tetapi terintegrasi dengan seni lainnya seperti seni tari, seni rupa dan seni teater. Karena itu, mata pelajaran Seni Musik pada dasarnya merupakan pendidikan seni yang berbasis musik.

Pendidikan Seni Musik diberikan kepada peserta didik di sekolah karena keunikan, kebermaknaan, dan kebermanfaatan terhadap kebutuhan perkembangan peserta didik, yang terletak pada pemberian pengalaman estetik dalam bentuk kegiatan berekspresi/berkreasi dan berapresiasi melalui strategi: "belajar dengan seni," "belajar melalui seni" dan "belajar tentang seni." Peran ini tidak dipeorleh peserta melalui mata pelajaran lain selain mata pelajaran Seni Musik. 
Pendidikan Seni Musik memiliki peranan dalam pembentukan pribadi peserta didik yang harmonis dengan memperhatikan kebutuhan perkembangan anak dalam mencapai multikecerdasan yang terdiri atas kecerdasan intrapersonal, interpersonal, visual spasial, musikal, linguistik, logik matematik, naturalis, kecerdasan kemampuan apresiasi seni musik, kecerdasan spiritual dan moral, dan kecerdasan emosional. Bidang seni rupa, musik, tari, dan teater memiliki kekhasan tersendiri sesuai dengan kaidah keilmuan masing-masing. Dalam pendidikan seni musik, aktivitas berkesenian harus menampung kekhasan tersebut yang tertuang dalam pemberian pengalaman mengembangkan konsepsi, apresiasi, dan kreasi. Semua ini diperoleh melalui upaya eksplorasi elemen, prinsip, proses, dan teknik berkarya dalam konteks musik masyarakat yang beragam.

Berkaitan dengan pembelajaran Seni Musik yang dilakukan selama ini ditunjukkan oleh penelitian yang dilakukan Badiran (2006) bahwa pembelajaran seni yang dirancang kurang melibatkan peserta didik dalam proses pembelajaran. Hal senada dijelaskan dari temuan penelitian Badiran, Sibuea dan Yusri (2008) bahwa pelaksanaan perlombaan nasional bidang seni musik hanya diikuti oleh kurang dari 5\% yang berstatus pelajar.

Rendahnya hasil belajar terjadi pada pembelajaran Seni Musik di SMP Negeri 1 Karang Baru Aceh Tamiang. Hal ini terlihat indikasinya dari rata-rata hasil belajar Seni Musik masih tergolong rendah, berdasarkan data yang diperoleh dari Pembantu Kepala Sekolah I Bidang Kurikulum SMP Negeri 1 Karang Baru Aceh Tamiang diperoleh rata-rata hasil belajar Seni Musik untuk tahun ajaran 2009/2010 adalah 6,57 sedangkan nilai kriteria ketuntasan minimal adalah 7,25.

Winkel (2009) menjelaskan rendahnya hasil belajar siswa dipengaruhi faktor internal dan faktor eksternal. Faktor internal berasal dari diri siswa seperti intelegensi, minat, dan motivasi belajar, sedangkan faktor eksternal adalah faktor yang berasal dari luar di antara strategi pembelajaran yang dilakukan guru. Strategi pembelajaran yang digunakan guruguru selama ini belum optimal sehingga menyebabkan timbulnya kebosanan siswa yang berakibat rendahnya hasil belajar. Untuk mengurangi atau bahkan menghindari strategi belajar yang terlalu monoton diupayakan berbagai strategi mengajar yang lebih efektif dalam menciptakan komunikasi yang multi arah, sehingga diharapkan juga menimbulkan dan meningkatkan interaksi yang proaktif dalam pembelajaran Seni Musik.

Strategi pembelajaran konstruktivisme merupakan kegiatan pembelajaran yang dilakukan dengan cara membangun dan menyusun pengetahuan baru dalam struktur kognitif siswa berdasakan pengalaman (Muijs dan Reynolds (2008). Pemberian materi dimulai dengan memberikan uraian tentang pengertian suatu konsep, prinsip atau prosedur, diikuti dengan contoh penerapannya dalam kehidupan sehari-hari dan diakhiri dengan latihan untuk menguasainya. Selanjutnya pembelajaran langsung merupakan kegiatan pembelajaran yang menggunakan guru sebagai satu-satunya sumber belajar, dalam arti guru sebagai pemegang kendali dan kontrol dalam menetapkan isi, metode pembelajaran dan menilai hasil belajar siswa. Strategi pembelajaran langsung diawali dengan kegiatan perencanaan pembelajaran dan didalamnya terdapat pemilihan, penetapan dan pengembangan metode untuk mencapai hasil belajar yang diinginkan, menentukan sumber belajar dan menilai hasil belajar sesuai dengan tujuan pembelajaran. Perbedaan karakteristik kedua strategi pembelajaran sebagaimana paparan di atas, maka akan memberikan perbedaan perolehan hasil belajar Seni Musik siswa.

Hergenhahn dan Olson (2008:8) menjelaskan bahwa belajar adalah perubahan prilaku atau potensi prilaku yang relatif permanen dan berasal dari pengalaman dan tidak bisa dinisbahkan ke temporary body state (keadaan tubuh temporer) seperti keadaan yang disebabkan oleh sakit, keletihan atau obatobatan. Selanjutnya Hergenhahn dan Olson (2008) menjelaskan lima hal yang harus diperhatikan berkaitan dengan belajar yaitu: (1) belajar diukur berdasarkan perubahan dalam prilaku, (2) perubahan prilaku (behavioral) ini relatif permanen, (3) perubahan prilaku itu tidak selalu terjadi secara langsung setelah proses belajar selesai, (4) perubahan prilaku berasal dari pengalaman atau latihan, dan (5) pengalaman atau latihan harus diperkuat

Woolfolk (2009) menjelaskan belajar adalah suatu proses perubahan permanen pada pengetahuan atau prilaku yang diakibatkan oleh pengalaman. Selanjutnya dijelaskan Woolfolk bahwa syarat yang harus dipenuhi dalam definisi belajar tersebut yaitu: (1) perubahan itu harus diwujudkan oleh pengalaman yaitu interaksi individu dengan lingkungannya, (2) 
perubahan itu tidak sebabkan oleh kematangan seperti tubuh menjadi lebih tinggi atau rambut yang mulai berubah, dan (3) perubahan akibat sakit, kelelahan atau kelaparan bukan termasuk definisi belajar tersebut.

Gredler (1994) menjelaskan belajar adalah proses orang memperoleh berbagai kecakapan, keterampilan dan sikap. Kemampuan individu untuk belajar ialah ciri penting yang membedakan jenisnya dari jenisjenis makhluk lainnya. Selanjutnya Gagne (1977) mendefinisikan belajar adalah perubahan dalam disposisi melalui usaha yang sungguhsungguh yang dilakukan dalam waktu tertentu dan bukan karena proses pertumbuhan. Dengan demikian dapatlah dimaknai bahwa belajar adalah usaha untuk memperoleh pengetahuan dan keterampilan yang ditandai dengan adanya perubahan tingkah laku individu dari tidak tahu menjadi tahu dan tidak dapat memiliki keterampilan menjadi memiliki keterampilan.

Kemp (1994) menjelaskan proses belajar dapat dikatakan berlangsung apabila individu sekarang mengetahui atau sekarang dapat melakukan sesuatu yang sebelumnya tidak diketahui atau tidak dapat dilakukan olehnya. Hal ini berkaitan dengan kemampuan individu dalam menguasai pengetahuan dan melakukan suatu keterampilan. Sedangkan De Porter, Reardon dan Nourie (2003) menjelaskan lima keterampilan yang merangsang belajar yaitu: (1) konsentrasi terfokus, (2) cara mencatat, (3) organisasi dan persiapan tes, (4) membaca cepat, dan (5) teknik mengingat

Selanjutnya berkaitan dengan hasil belajar, Kemp (1994) menjelaskan hasil belajar akan terlihat dengan adanya tingkah laku baru pada tingkat kemampuan berpikir atau kemampuan jasmaniah. Sedangkan Djamarah dan Zain (2002) menjelaskan bahwa hasil belajar adalah penguasaan peserta didik terhadap bahan/materi pelajaran yang telah diberikan ketika proses mengajar berlangsung. Bahan atau materi pelajaran kemudian selanjutnya diujikan kepada siswa untuk mengetahui penguasaannya.

Howard Kingsley dalam Sudjana (2002) menjelaskan tiga macam hasil belajar, yakni: (1) keterampilan dan kebiasaan, (2) pengetahuan dan pengertian dan (3) sikap dan cita-cita dapat diisi dengan bahan yang ditetapkan dalam kurikulum sekolah. Selanjutnya Gagne (1977) menjelaskan terdapat lima tipe hasil belajar yaitu: (1), intelektual skill, (2) cognitive strategy (3) verbal information, (4) attitude, dan (5) motor skill.

Merril dan Twitchell (1994) mengelompokkan hasil belajar ke dalam dua dimensi yaitu tingkat kinerja (performance) dan tipe isi (content matrix). Dimensi tingkat kinerja terdiri dari mengingat, menggunakan, dan menemukan. Mengingat berkaitan dengan kinerja yang menuntut siswa melakukan penelusuran struktur ingatan agar dapat mengungkapkan kembali konstruk-konstruk yang telah disimpan di dalamnya. Menggunakan berkaitan dengan kinerja yang menuntut siswa menerapkan suatu abstraksi pada kasus-kasus khusus. Menemukan berkaitan dengan unjuk kerja yang menuntut siswa menemukan atau mengembangkan abstraksi baru.

Bloom dkk (dalam Arikunto, 2002) membagi tipe hasil belajar kepada tiga kelompok, yaitu: (1) domain kognitif, (2) domain afektif, dan (3) domain psikomotorik. Domain kognitif terdiri dari enam tingkatan yaitu: pengetahuan, pemahaman penerapan, analisis, sintesis dan evaluasi. Pengetahuan (knowledge) berisikan kemampuan untuk mengenali dan mengingat peristilahan, definisi, fakta-fakta, gagasan, pola, urutan. Pemahaman (comprehension) berkaitan dengan kemampuan untuk membaca dan memahami gambaran, laporan, tabel, diagram, arahan, peraturan. Penerapan (application), pada tingkat ini berkaitan dengan kemampuan untuk menerapkan gagasan, prosedur, metode, rumus, teori di dalam kondisi kerja. Analisis (analyis) berkaitan dengan kemampuan menganalisa informasi yang diterima dan membagi-bagi atau menstrukturkan informasi ke dalam bagian yang lebih kecil untuk mengenali pola atau hubungannya, dan mampu mengenali serta membedakan faktor penyebab dan akibat dari sebuah skenario yang rumit. Sintesis (syntesis) berkaitan dengan kemampuan menjelaskan struktur atau pola dari sebuah skenario yang sebelumnya tidak terlihat, dan mampu mengenali data atau informasi yang harus didapat untuk menghasilkan solusi yg dibutuhkan. Evaluasi (evaluation) berkaitan dengan kemampuan untuk memberikan penilaian terhadap solusi, gagasan, metodologi dan sebagainya dengan menggunakan kriteria atau standar yang ada untuk memastikan nilai efektivitas atau manfaatnya.

Berkaitan dengan mata ajar Seni Musik tingkat sekolah menengah pertama Departemen Pendidikan Nasional (2006) menjelaskan mata 
pelajaran seni Musik untuk tingkat sekolah menengah pertama bertujuan agar peserta didik memiliki kemampuan: (1) memahami konsep dan pentingnya seni Musik, (2) menampilkan sikap apresiasi terhadap seni Musik, (3) menampilkan kemampuan apresiasi seni musik melalui seni Musik dan (4) menampilkan peran serta dalam seni Musik dalam tingkat lokal, regional, maupun global.

Pendekatan pembelajaran, dijelaskan Seels dan Richey (1994) merupakan strategi pembelajaran yang spesifik untuk menyeleksi serta mengurutkan peristiswa belajar atau kegiatan pembelajaran dalam suatu pelajaran. Sanjaya (2007:125) menjelaskan pendekatan adalah titik tolak atau sudut pandang terhadap proses pembelajaran. Hal senada diungkapkan Gulo (2008) pendekatan merupakan titik tolak atau sudut pandang dalam memandang seluruh masalah yang ada dalam program pembelajaran. Sudut pandang tertentu menggambarkan cara berpikir dan sikap guru dalam menyelesaikan persoalan dalam pembelajaran. Dalam melaksanakan tugasnya seorang guru selalu menghadapi berbagai permasalahan tentang bagaimana cara mengajar yaitu memilih pendekatan pembelajaran yang paling sesuai sehingga tujuan-tujuan pembelajaran dapat dicapai dengan baik.

Dick, Carey dan Carey (2005) berpendapat bahwa strategi pembelajaran adalah prosedur atau tahapan kegiatan belajar yang digunakan dalam rangka membantu peserta didik mencapai tujuan pembelajaran tertentu. Selanjutnya Dick, Carey dan Carey (2005) menjelaskan bahwa strategi pembelajaran memuat lima komponen utama, yaitu: (1) aktivitas pembelajaran pendahuluan, (2) penyampaian informasi, (3) partisipasi siswa, (4) tes, dan (5) kegiatan lanjutan.

Suparman (2001:167) mendefinisikan strategi pembelajaran sebagai perpaduan dari (1) urutan kegiatan instruksional, (2) cara pengorganisasian materi pengajaran dan siswa, (3) peralatan dan bahan dan (4) waktu yang digunakan dalam proses pembelajaran. Kedua definisi yang dikemukakan para ahli di atas pada prinsipnya lebih menekankan pada aspek komponen dan prosedur pengajaran.

Hamalik (1993:2) mendefinisikan strategi pembelajaran adalah sebagai sistem menyeluruh yang terdiri dari sejumlah komponen yaitu komponen masukan (input), komponen proses, dan komponen produk (output). Romizowski (1981) berpendapat bahwa strategi pembelajaran merupakan suatu kegiatan menyeluruh yang dapat dibedakan menjadi dua strategi dasar, yaitu ekspositori dan inquiri. Kedua strategi ini dapat dipandang sebagai dua ujung yang sejalan dalam suatu kontinum strategi, hal ini erat sekali kaitannya dengan deduktif di mana strategi ini dimulai dengan penyajian informasi mengenai prinsip atau kaidah kemudian diikuti dengan tes penguasaan, penerapan dalam bentuk contoh dan penerapan pada situasi tertentu. Sedangkan strategi inquiri/diskoveri didasarkan pada teori belajar pengalaman yang disebut juga teori belajar pengalaman.

Merill (1981) mengklasifikasikan strategi pembelajaran atas tiga dasar (1) tujuan pengajaran meliputi sepuluh kombinasi antara jenis materi dan tingkah laku yang diharapkan, (2) cara mempresentasikan materi yaitu dari tingkat yang khusus ke tingkat yang umum atau sebaliknya dari tingkat yang umum ke tingkat khusus, (3) bentuk respon siswa dibedakan atas strategi ekspositori dan inkuri. Romizowski (1981) menyatakan bahwa setiap strategi pembelajaran yang dikembangkan selalu mencerminkan posisi teoritis yang dianut tentang bagaimana seharusnya pembelajaran itu dilaksanakan. Oleh karena itu guru sebagai penyelenggara kegiatan pembelajaran dituntut mampu mengupayakan terjadinya interaksi siswa dengan komponen sistem pembelajaran yang lain secara optimal.

Pembelajaran konstruktivisme berpijak pada teori yang dikemukakan Piaget yaitu anak membangun sendiri skemanya serta membangun konsep-konsep melalui pengalaman-pengalamannya. Dalam hal ini, Piaget membedakan perkembangan kognitif seorang anak menjadi empat taraf, yaitu (1) taraf sensori motor, (2) taraf pra operasional, (3) taraf operasional konkrit, dan (4) taraf operasional formal (Slavin, 2009).

Selanjutnya Slavin (2009) menjelaskan bahwa pembelajaran konstruktivisme menekankan masing-masing siswa menemukan dan mengubah informasi yang rumit dengan memeriksa informasi baru terhadap aturan lama dan mengubah aturan apabila hal itu tidak lagi berguna. Muijs dan Reynolds (2008) menjelaskan bahwa pembelajaran konstruktivisme yaitu siswa mengkonstruksikan pengetahuan secara aktif dan tidak menerima begitu saja dari guru. Belajar adalah sebuah pencarian makna, di mana guru berperan mendorong siswa untuk mengkonstruksikan makna dengan menstrukturisasikan berbagai kegiatan di seputar ide-ide besar dan eksplorasi, 
memberi siswa cukup waktu untuk mengeksplorasi berbagai konsep secara seksama dan menghubungkan pengetahuan baru dengan apa yang sudah diketahui siswa. Selanjutnya Arends (2008) menjelaskan pembelajaran konstruktivisme adalah pandangan yang menjadi belajar adalah sebuah kegiatan sosial dan kultural dan pengetahuan bersifat personal oleh karena itu siswa mengkonstruksi makna melalui interaksi dengan orang lain.

Siswa beradaptasi secara fisik dengan lingkungan kelas dan sekolahnya demikian juga struktur pemikiran siswa. siswa berhadapan dengan tantangan, pengalaman, gejala baru, dan persoalan yang harus ditanggapinya secara kognitif sehingga siswa mengembangkan skema pikiran lebih umum atau rinci, atau perlu perubahan, menjawab dan menginterpretasikan pengalaman-pengalaman tersebut, dengan cara itu pengetahuan siswa terbentuk dan selalu berkembang. Proses tersebut dijelaskan Slavin (2009) yaitu: (1) skema/skemata adalah struktur kognitif yang dapat membuat seseorang beradaptasi dan terus mengalami perkembangan mental dalam interaksinya dengan lingkungan. Skema juga berfungsi sebagai kategori-kategori untuk mengidentifikasikan rangsangan yang datang dan terus berkembang, (2) asimilasi adalah proses kognitif perubahan skema yang tetap mempertahankan konsep awalnya, hanya menambah atau merinci, (3) akomodasi adalah proses pembentukan skema atau karena konsep awal sudah tidak cocok lagi, dan (4) equilibrasi adalah keseimbangan antara asimilasi dan akomodasi sehingga seseorang dapat menyatukan pengalaman luar dengan struktur dalamnya (skemata).

Keunggulan

pembelajaran

konstruktivisme di antaranya: (1) siswa berpikir untuk menyelesaikan masalah, (2) siswa lebih paham dan boleh mengaplikasikannya dalam semua situasi, (3) pengetahuan akan lebih lama diingat, (4) siswa lebih yakin dalam menghadapi dan menyelesaikan masalah, (5) adanya interaksi antara sesama siswa dan guru dalam membina pengetahuan baru, dan (6) siswa senang belajar dalam mendapatkan pengetahuan yang baru.

Zahorik (1995) menjelaskan terdapat lima elemen yang harus diperhatikan dalam melaksanakan pembelajaran konstruktivisme yaitu: (1) pengaktifan pengetahuan yang sudah ada (activing knowledge), (2) pemerolehan pengetahuan baru (acquining knowledge), hal ini dilakukan dengan cara mempelajari secara keseluruhan dulu kemudian memperhatikan detailnya, (3) pemahaman pengetahuan (understanding knowledge), yaitu dilakukan dengan cara menyusun konsep sementara (hipotesis), melakukan sharing kepada orang lain agar mendapatkan tanggapan dan atas dasar tanggapan konsep tersebut direvisi dan dikembangkan, (4) mempraktekkan pengetahuan dan pengalaman tersebut (applying knowledge), dan (5) melakukan refleksi (reflecting knowledge) terhadap strategi pengembangan pengetahuan tersebut.

$$
\text { Selanjutnya Zahorik }
$$

menjelaskan dalam menerapkan penerapan pembelajaran konstruktivisme terdapat 7 komponen dasar yaitu: (1) konstruktivisme, (2) menemukan (inquiry), (3) bertanya (questioning), (4) masyarakat belajar (learning community), (5) pemodelan (modelling), (6) refleksi (reflection), dan (7) penilaian yang sebenarnya (authentic assessment). Konstruktivisme berkaitan dengan proses aktif pada diri siswa untuk mengkonstruksi pengetahuan. Peran guru memfasilitasi proses tersebut dengan cara: (1) menjadikan pengetahuan bermakna dan relevan bagi siswa, (2) memberikan kesempatan siswa menemukan dan menerapkan idenya sendiri, dan (3) menyadarkan siswa agar menerapkan strategi mereka sendiri dalam belajar. Sehingga pengetahuan tumbuh berkembang melalui pengalaman, pemahaman berkembang semakin dalam dan semakin kuat apabila selalu diuji dengan pengalaman baru.

Selanjutnya dalam penelitian ini, sintaks pembelajaran konstruktivisme yang peneliti terapkan dalam kegiatan pembelajaran adalah sintaks yang dikemukakan oleh Muijs dan Reynolds (2008) berikut: (1) fase awal yaitu guru mengukur pengetahuan siswa yang dilakukan dengan menyampaikan pertanyaan terbuka maupun dengan melakukan tes kemampuan awal, (2) fase eksplorasi yaitu aktivitas siswa adalah mengeksplorasi pengetahuan, ide atau konsep awal yang diperoleh dari pengalaman sehari-hari atau diperoleh dari pembelajaran pada tingkat kelas sebelumnya. Selanjutnya siswa mengutarakan ide-ide dan merumuskan hipotesis. Siswa melakukan klasifikasi pendapat atau ide-ide yang telah ada, (3) fase refleksi yaitu kegiatan siswa untuk melihat kembali kegiatan yan dilakukan sebelum yaitu pada fase eksplorasi, hal ini dimaksudkan untuk mendorong siswa untuk menjelaskan suatu konsep dengan kalimat atau pemikiran sendiri, meminta bukti 
dan klarifikasi atas penjelasan siswa dan saling mendengar secara kritis penjelasan antar siswa dan guru. Dengan adanya refleksi tersebut terungkap konsep yang dibahas, secara baik dan benar, dan (4) fase aplikasi dan diskusi yaitu kegiatan kelas untuk mendiskusikan berbagai temuan dan menarik kesimpulan.

Sebelum dipaparkan lebih lanjut mengenai pembelajaran langsung maka terdapat pembelajaran tidak langsung (non directive instruction). Dalam hal ini Joyce, Weil dan Calhoun (2009) menjelaskan pembelajaran tidak langsung menekankan pada upaya memfasilitasi belajar dengan tujuan utamanya adalah membantu siswa mencapai integrasi pribadi, efektivitas pribadi dan penghargaan terhadap dirinya secara realistis. Kunci utama keberhasilan dalam penerapan pembelajaran tidak langsung adalah kemitraan guru dan siswa, dalam hal ini guru hendaknya jangan sekali-sekali menyelesaikan masalah belajar siswa dengan cara menjelaskan bagaimana seharusnya cara belajar yang baik secara menggurui tetapu guru mendorong siswa mengekspresikan perasaannya tentang permasalahan yang dihadapinya dan selanjutnya memberikan kesempatan kepada siswa untuk menentukan dan menemukan jawaban atas permasalahannya.

Pembelajaran langsung yang merupakan aplikasi dari penerapan teori behaviorisme yang dikemukakan Skinner. Menurut Skinner, individu telah dianggap belajar sesuatu apabila individu tersebut mampu menunjukkan perubahan tingkah laku. Belajar dimaknai merupakan perubahan tingkah laku yang terjadi berdasarkan paradigma stimulusrespon, yaitu suatu proses memberikan respon tertentu kepada stimulus yang datang dari luar (Hamid, 2007). Lebih lanjut Hamid menjelaskan bahwa menurut teori ini yang terpenting adalah masukan (input) yang berupa stimulis dan keluaran (output) yang berupa respon, sedangkan apa yang terjadi di antara stimulus dan respon itu dianggap tidak penting sebab tidak diamati.

Faktor lain yang terpenting dalam pandangan teori behaviorisme adalah faktor penguatan (reinforcement). Penguatan apa saja yang dapat memperkuat timbulnya respon, apabila penguatan ditambahkan disebut positive reinforcement maka respon akan semakin kuat dan apabila penguatan dikurangi maka disebut negative reinforcement. Dengan kata lain bahwa positive reinforcement apabila suatu stimulus tersebut menyenangkan, sedangkan negative reinforcement apabila suatu stimulus tidak menyenangkan.

Aplikasi dari penerapan teori behaviorisme adalah strategi pembelajaran langsung dijelaskan Slavin (2008), yaitu pembelajaran langsung digunakan untuk menggambarkan pelajaran yang dilakukan guru dalam menyampaikan informasi langsung kepada siswa dengan menata waktu pelajaran untuk mencapai sasaran yang telah ditentukan dengan jelas seefisien mungkin. Santrock (2007) menjelaskan pembelajaran langsung adalah teacher-centered yang terstruktur yang dicirikan oleh arahan dan kontrol guru, ekspektasi guru yang tinggi atas kemajuan murid, pengunaan waktu yang dilakukan siswa untuk mengerjakan tugas-tugas akademik dan usaha guru untuk menghindari pengaruh negatif terhadap siswa.

Trianto (2009) menjelaskan pembelajaran langsung adalah salah satu strategi mengajar yang dirancang khusus untuk menunjang proses belajar siswa yang berkaitan dengan pengetahuan deklaratif dan pengetahuan prosedural yang terstruktur dengan baik yang dapat diajarkan dengan pola kegiatan bertahap, selangkah demi selangkah. Selanjutnya Trianto (2009) menjelaskan ciri-ciri pembelajaran .langsung adalah: (1) adanya tujuan pembelajaran dan pengaruh strategi pada siswa termasuk prosedur penilaian, (2) sintaks atau pola keseluruhan dan alur kegiatan pembelajaran, dan (3) sistem pengelolaan dan lingkungan belajar strategi yang diperlukan agar kegiatan pembelajaran tertentu dapat berlangsung dengan berhasil.

Slavin (2008) menjelaskan tentang bagian-bagian pelajaran pada pembelajaran langsung yaitu: (1) ungkapkan sasaran pelajaran dan arahkan siswa pada pelajaran tersebut, (2) ulangi kembali prasyarat, (3) sajikan bahan baru, (4) lakukan pemeriksaan pembelajaran, (5) sediakan latihan mandiri, (6) nilai kinerja dan berikan umpan balik, dan (7) berikan latihan terdistribusi dan periksa.

$$
\text { Trianto (2009) menjelaskan }
$$

perencanaan pelaksanaan pembelajaran langsung adalah: (1) merumuskan tujuan, (2) memilih isi, (4) melakukan analisis tugas, dan (5) merencanakan waktu dan ruang. Merumuskan tujuan terdiri dari tiga bagian yaitu: (1) prilaku siswa, apa yang akan dilakukan siswa/jenis-jenis prilaku siswa yag diharapkan guru untuk dilakukan sebagai bukti bahwa tujuan itu telah dicapai, (2) situasi pengetesan, di bawah kondisi tertentu prilaku 
itu akan teramati atau diharapkan terjadi, dan (3) kriteria kinerja, ditetapkan standar atau tingkat kinerja sebagai standar atau tingkat kinerja yang dapat diamati.

\section{Selanjutnya Trianto}

menjelaskan langkah-langkah pembelajaran langsung yang terdiri dari: (1) menyampaikan tujuan dan menyiapkan siswa, (2) presentasi dan demonstrasi, (3) berlatih, (4) mengecek pemahaman dan memberikan umpan balik dan (5) memberikan kesempatan latihan mandiri. Menyampaikan tujuan dilakukan guru melalui rangkuman rencana pembelajaran dengan cara menuliskan di papan tulis atau menempelkan informasi tertulis pada papan bulletin yang berisi tahap-tahap dan isinya serta alokasi waktu yang disediakan, sedangkan tahap menyiapkan siswa bertujuan untuk menarik perhatian siswa, memusatkan perhatian siswa pada pokok pembicaraan dan mengingatkan kembali pada hasil belajar yang telah dimilikinya yang relevan dengan materi ajar yang akan dipelajari.

Berlatih merupakan kegiatan mendemonstrasikan sesuatu dengan benar diperlukan latihan yang intensif dan memperhatikan aspek-aspek penting dari keterampilan atau konsep-konsep yang didemonstrasikan. Memberikan latihan terbimbing, merupakan salah satu tahap penting dalam pembelajaran langsung di mana keterlibatan siswa secara aktif dalam kegiatan latihan terbimbing dapat meningkatkan retensi, membuat belajar berlangsung dengan lancar dan memungkinkan siswa menerapkan kosenp/keterampulan pada situasi baru. Hal-hal yang harus diperhatikan dalam menerapkan latihan dijelaskan Trianto (2009) adalah: (1) menugasi siswa melakukan latihan singkat dan bermakna, (2) memberikan latihan pada siswa sampai benar-benar menguasai konsep/keterampilan yang dipelajari, (3) hatihati terhadap latihan yang berkelanjutan, pelatihan yang dilakukan terus menerus dalam waktu yang lama dapat menimbulkan kejenuhan pada siswa, dan (4) memperhatikan tahap-tahap awal latihan, yang mungkin saja siswa melakukan keterampilan yang kurang benar atau bahka salah tanpa disadari.

Mengecek pemahaman berkaitan dengan kegiatan guru mengetahui pemahaman siswa dengan memberikan pertanyaan lisan atau tertulis dan guru memberikan respon terhadap jawaban siswa. Kegiatan ini merupakan aspek penting dalam pembelajaran langsung, karena tanpa mengetahui hasilnya, latihan tidak banyak manfaatnya bagi siswa. Memberikan umpan balik dapat dilakukan siswa dengan berbagai cara misalnya umpan balik secara lisan, tes dan komentar tertulis. Tanpa umpan balik, siswa tak mungkin dapat memperbaiki kekurangannya dan tidak dapat mencapai tingkat penguasaan keterampilan yang mantap. Pedoman dalam memberikan umpan balik dijelaskan Trianto (2009) Trianto (2009) adalah: (1) memberikan umpan balik sesegera mungkin setelah latihan, hal ini tidak berarti umpan balik perlu diberikan kepada siswa dengan seketika, namun umpan balik seharusnya diberikan sukup segera setelah latihan, sehingga siswa dapat mengingat dengan jelas kinerjanya sendiri, (2) mengupayakan umpan balik jelas dan spesifik agar dapat membantu siswa, (3) umpan balik ditujukan langsung pada tingkah laku dan bukan pada maksud yang tersirat dalam tingkah laku tersebut, (4) menjaga umpan balik sesuai dengan tingkat perkembangan siswa. Umpan balik harus diberikan secara hati-hati agar berguna. Terkadang siswa diberi umpan balik terlalu banyak atau umpan balik yang terlalu rumit bagi siswa untuk menanganinya, (5) memberikan umpan balik pada kinerja yang benar. Tentunya setiap siswa lebih menyukai umpan balik yang positif daripada yang negative. Pada umumnya pujian akan diterima sedangkan umpan balik negative mungkin ditolak, (6) memberi umpan balik negatif dilakukan dengan benar, agar siswa mengetahui kelemahan atau kesalahan yang dilakukannya, (7) membantu siswa memusatkan perhatiannya pada proses dan bukan pada hasil. Merupakan tanggung jawab guru agar siswa memusatkan perhatiannya pada proses atau teknik tertentu, dan (8) mengajari siswa cara memberi umpan balik kepada dirinya sendiri dan bagaimana menilai keberhasilan kinerjanya sendiri.

Memberikan kesempatan latihan mandiri dilakukan guru dengan memberikan tugas kepada siswa untuk menerapkan pengetahuan dan keterampilan yang baru saja diperoleh secara mandiri. Kegiatan ini dilakukan oleh siswa secara pribadi yang dilakukan di rumah atau di luar jam pelajaran. Beberapa hal yang harus menjadi perhatian guru dalam memberikan latihan mandiri adalah: (1) tugas rumah diberikan bukan merupakan kelanjutan dari proses pembelajaran, tetapi merupakan kelanjutan latihan untuk pembelajaran berikutnya, (2) guru seyogyanya menginformasikan kepada orang tua siswa tentang keterlibatan mereka dalam membimbing siswa di rumah, dan (3) guru 
memberikan umpan balik tentang latihan yang diberikan kepada siswa.

Berdasarkan uraian di atas, maka dapatlah dipahami bahwa dalam penelitian ini peneliti mengambil sintaksi pembelajaran langsung yang dikemukakan Trianto (2009) yaitu penyajian materi ajar kepada siswa dengan menerapkan langkah-langkah pembelajaran: (1) menyampaikan presentasi materi ajar Seni Musik, kemudian dilanjutkan dengan penyajian materi ajar yang dilakukan guru dengan mencontohkan secara langsung, (2) siswa mengerjakan latihan yang diberikan guru berupa soal-soal, (3) guru mengecek pemahaman siswa terhadap materi ajar dengan memeriksa soal-soal latihan yang telah diberikan kemudian dilanjutkan dengan memberikan umpan balik terutama kepada siswa yang belum atau kurang memahami materi ajar, dan 94) menutup pelajaran dengan memberikan kesimpulan dengan cara merangkum materi ajar kemudian memberikan latihan mandiri secara individual kepada siswa.

Apresiasi dalam bahasa Inggris disebut appreciaton yang berarti "penghargaan". Apresiasi adalah penghargaan terhadap seni. Ungkapan kata apresiasi masa sekarang sering dipakai baik dalam bentuk pidato-pidato maupun dalam surat-surat kabar atau majalah. Seakan-akan hal itu sudah menjelma menjadi Bahasa Indonesia, adapun inti maksudnya tidak lain adalah penghargaan masyarakat terhadap sesuatu hal.

Menurut Sugriwa (dalam Nooryan, 2008) seni berasal dari bahasa Sanskerta yang berarti penyembahan, pelayanan, dan pemberian. Sedangkan Padmapuspita (dalam Nooryan, 2008) menunjuk kemungkinan bahwa seni berasal dari bahasa Belanda yaitu genie. Merriam Webstar Collegiate Dictionary (dalam Nooryan, 2008) menyebutkan beberapa defenisi tentang seni, di antaranya adalah skill acquired by experience, study, or observation the art $f$ making friends.

Sugriwa (dalam Nooryan, 2008) selanjutnya menjelaskan bahwa seni berkaitan dengan segala perbuatan manusia yang timbul dari kehidupan perasaannya hingga dapat menggerakkan jiwa dan perasaan manusia. Seni adalah aktivitas batin dengan pengalaman estetik yang dinyatakan dalam bentuk agung yang mempunyai daya membangkitkan rasa takjub dan haru. Agung merupakan pengejewantahan pribadi kreatif yang telah matang dan masak. Takjub adalah getaran emosi yang terjadi karena adanya rangsangan yang kuat dari sesuatu yang agung sedangkan Haru adalah rasa yang dimiliki atau dimulai dari simpati dan empati yang kemudian dilebur menjadi

Apresiasi seni musik merupakan suatu proses sadar yang dilakukan seseorang dalam menghargai dan memahami karya seni musik (Nooryan, 2008). Sedangkan pendapat HB. Sutopo (1987) mengatakan apresiasi seni musik merupakan proses kadar yang dilakukan oleh penghayat dalam menghadapi dan menghagai karya seni musik. Pengertian apresiasi seni musik juga dikemukakan oleh O. Smith (1971) yang mengatakan bahwa apresiasi seni musik merupakan proses pengenalan nilai karya seni, untuk menghargainya dan menafsir makna yang terkandung didalamnya. Apresiasi menuntut keterampilan dan kepekaan estetik untuk memungkinkan seseorang mendapatkan pengalaman estetik dalam mengamati karya seni, apresiasi bukanlah proses pasif, ia merupakan proses aktif dan secara efektif mengerti nilai suatu karya seni yaitu untuk mendapatkan pengalaman estetik (Feldman, 1981).

Musik merupakan seni pengungkapan ide, gagasan dan hasil ekspresi jiwa manusia melalui bunyi yang dituangkan melalui vokal dan instrumen dengan unsur dasar melodi, harmoni dan irama (Soeharto, 1992). Sementara Dello Joio (dalam Nooryan, 2008) berpendapat bahwa musik dapat memperluas pengetahuan, pandangan dan hal-hal lain di luar musik. Pengenalan terhadap musik akan menumbuhkan rasa penghargaan terhadap nilai seni musik. Rangkaian bunyi yang dapat didengar dapat memberikan rasa indah, yang diwujudkan dalam bentuk rangkaian nada-nada atau bunyi lain yang mengandung ritme dan harmoni. Selain itu musik juga dapat memberikan rasa puas bagi yang mendengarnya karena adanya keserasian susunan dari rangkaian nada-nada yang dibunyikan.

Masalah penelitian ini dirumuskan sebagai berikut : (1) Apakah hasil belajar Seni Musik siswa yang diajar dengan strategi pembelajaran konstruktivisme lebih unggul dibandingkan dengan hasil belajar Seni Musik siswa yang diajar dengan strategi langsung?; (2) Apakah hasil belajar Seni Musik siswa dengan tingkat kemampuan apresiasi seni musik tinggi lebih unggul dibandingkan dengan hasil belajar siswa dengan kemampuan apresiasi seni musik rendah?; dan (3) Apakah terdapat interaksi antara strategi pembelajaran dan kemampuan 
apresiasi seni musik dalam mempengaruhi belajar Seni Musik?

\section{METODE}

Penelitian dilaksanakan di Sekolah Menengah Pertama (SMP) Negeri Kabupaten Aceh Tamiang, baik untuk uji coba instrumen maupun pelaksanaan penelitian. Populasi penelitian ini adalah siswa SMP 1 Negeri Karang Baru kelas VIII yang terdiri dari 7 kelas dengan jumlah siswa seluruhnya adalah 266 siswa dan SMP Negeri 1 Kota Kuala Simpang kelas VIII terdiri dari 6 kelas berjumlah 231 .

Teknik penentuan sampel digunakan cluster random sampling. Teknik ini dipilih karena yang disampling dari populasi adalah jumlah kelas yaitu $\mathbf{7}$ kelas bukan jumlah siswa dalam populasi. Sampel yang diambil terdiri dari dua kelompok yaitu, satu kelompok kelas dilakukan pembelajaran menggunakan pembelajaran konstruktivisme dan satu kelas lainnya dilakukan pembelajaran langsung. Sebelum pembelajaran diselenggarakan, guru yang mengajar di kelas pembelajaran konstruktivisme dan pembelajaran langsung terlebih dahulu diberikan petunjuk khusus mengenai cara penyajian materi pembelajaran.

Metode yang dipergunakan dalam penelitian ini adalah metode kuasi-eksperimen. Metode ini dipilih karena kelas yang dipakai untuk perlakuan baik untuk kelas pembelajaran dengan konstruktivisme maupun kelas pembelajaran langsung merupakan kelas yang sudah terbentuk sebelumnya dan karakteristik siswa yang dikontrol adalah kemampuan apresiasi seni musik. Desain penelitian yang digunakan dalam penelitian ini adalah faktorial $2 \times 2$ sebagaimana terlihat pada Tabel 1 berikut:

Tabel 1. Matrik Rancangan Penelitian

\begin{tabular}{|c|c|c|}
\hline Kemampuan Apresiasi Seni & \multicolumn{2}{|c|}{ Strategi Pembelajaran $(\mathrm{A})$} \\
\cline { 2 - 3 } Musik $(\mathrm{B})$ & Konstruktivisme $\left(\mathrm{A}_{1}\right)$ & Langsung $\left(\mathrm{A}_{2}\right)$ \\
\hline Tinggi $\left(\mathrm{B}_{1}\right)$ & $\mathrm{A}_{1} \mathrm{~B}_{1}$ & $\mathrm{~A}_{2} \mathrm{~B}_{1}$ \\
\hline Rendah $\left(\mathrm{B}_{2}\right)$ & $\mathrm{A}_{1} \mathrm{~B}_{2}$ & $\mathrm{~A}_{2} \mathrm{~B}_{1}$ \\
\hline
\end{tabular}

Keterangan :

$\mathrm{A}_{1} \mathrm{~B}_{1}=$ Hasil belajar Seni Budaya siswa yang diajar dengan strategi pembelajaran konstruktivisme dan kemampuan apresiasi seni musik tinggi

$A_{1} B_{2}=$ Hasil belajar Seni Budaya siswa yang diajar dengan strategi pembelajaran konstruktivisme dan kemampuan apresiasi seni musik rendah

$\mathrm{A}_{2} \mathrm{~B}_{1}=$ Hasil belajar Seni Budaya siswa yang diajar dengan strategi pembelajaran langsung dan kemampuan apresiasi seni musik tinggi

$\mathrm{A}_{2} \mathrm{~B}_{2}=$ Hasil belajar Seni Budaya siswa yang diajar dengan strategi pembelajaran langsung dan kemampuan apresiasi seni musik rendah

Teknik analisis data yang digunakan dalam penelitian ini adalah: (1) analisis deskriptif dan (2) analisis inferensial. Teknik analisis deskriptif dimaksudkan untuk mendeskripsikan data hasil belajar Seni Budaya siswa yang meliputi rata-rata, median, modus, varians dan simpangan baku, selanjutnya data disajikan dalam bentuk tabel distribusi frekuensi dan histrogram. Sedangkan teknik analisis inferensial dimaksudkan untuk menguji hipotesis penelitian yang dilakukan dengan menggunakan teknik analisis varians (ANAVA) fakorial $2 \times 2$.

Sebelum hipotesis diuji terlebih dahulu dilakukan uji persyaratan analisis yaitu (1) uji normalitas dengan menggunakan uji Liliefors, dan (2) uji homogenitas menggunakan teknik uji Fisher dan Bartlett. Selanjutnya dalam pengujian hipotesis penelitian, maka hipotesis statistik dapat dinyatakan sebagai berikut :

Hipotesis pertama : Ho : $\mu \mathrm{SP}_{\text {Konstruktivisme }}=\mu$ $\mathrm{PP}_{\text {Langsung }}$

PP $P_{\text {Langsung }}$

Hipotesis kedua : Ho $: \mu \mathrm{KASM}_{\text {Tinggi }}=\mu$ $\mathrm{KASM}_{\text {Rendah }}$

$\mathrm{KASM}_{\text {Rendah }}$

Hipotesis ketiga : Ho : PP $><\mathrm{KASM}=0$

$\mathrm{Ha}: \mathrm{PP}><\mathrm{KASM} \neq 0$

Setelah pengujian hipotesis dilakukan maka dilakukan pengujian uji lanjut dengan menggunakan uji Tukey. Uji Tukey digunakan karena jumlah anggota kelompok sampel pada masing-masing sel berjumlah sama. 


\section{HASIL DAN PEMBAHASAN}

\section{Hasil}

Pengujian hipotesis penelitian pertama, kedua dan ketiga dilakukan dengan menggunakan analisis varians faktorial $2 \times 2$. Rangkuman hasil perhitungannya dapat dilihat pada Tabel 2 .

Tabel 2. Rangkuman Anava Faktorial 2 x 2

\begin{tabular}{|c|c|c|c|c|c|}
\hline Sumber Variasi & $\mathrm{dk}$ & $\mathrm{Jk}$ & $\mathrm{Rjk}$ & F-hitung & F-tabel $_{(1,100)}$ \\
\hline Strategi Pembelajaran & 1 & 81,38 & 81,38 & 9,58 & 3,94 \\
Kemampuan Seni Musik & 1 & 216,34 & 216,34 & 25,48 & 3,94 \\
Interaksi & 1 & 297,85 & 297,85 & 35,08 & 3,94 \\
Galat & 100 & 849,32 & 8,49 & & \\
\hline Total & 103 & 1444,89 & - & - & \\
\hline
\end{tabular}

Untuk mengetahui interaksi antara strategi pembelajaran dan kemampuan apresiasi seni musik terhadap hasil belajar Seni Musik, maka dilakukan uji lanjut dengan uji Tukey. Rangkuman perhitungan uji Tukey dapat dilihat pada Tabel 3.

Tabel 3. Rangkuman Uji Tukey

\begin{tabular}{|l|c|c|c|}
\hline \multicolumn{2}{|c|}{ Hipotesis Statistik } & $\mathrm{F}_{\text {-hitung }}$ & $\mathrm{F}_{\text {-tabel }(3,100)}$ \\
\hline $\mathrm{H}_{\mathrm{O}: \mu 11=\mu 12}$ & $\mathrm{Ha}_{: \mu 11>\mu 12}$ & 5,23 & 2,70 \\
\hline $\mathrm{H}_{\mathrm{O}: \mu 11=\mu 21}$ & $\mathrm{Ha}: \mu 11>\mu 21$ & 7,40 & 2,70 \\
\hline $\mathrm{H}_{\mathrm{O}: \mu 11=\mu 22}$ & $\mathrm{Ha}: \mu 11>\mu 22$ & 6,33 & 2,70 \\
\hline $\mathrm{H}_{\mathrm{O}: \mu 12=\mu 21}$ & $\mathrm{Ha}_{: \mu 12>\mu 21}$ & 2,16 & 2,70 \\
\hline $\mathrm{H}_{\mathrm{O}: \mu 12=\mu 22}$ & $\mathrm{Ha}: \mu 12>\mu 22$ & 1,10 & 2,70 \\
\hline $\mathrm{H}_{\mathrm{O}: \mu 21=\mu 22}$ & $\mathrm{Ha}: \mu 21>\mu 22$ & 1,06 & 2,70 \\
\hline
\end{tabular}

Berdasarkan Tabel 3 maka hasil uji Tukey menunjukkan dari enam kombinasi pengujian rata-rata hasil belajar Seni Musik maka terdapat tiga pengujian yang menunjukkan hasil yang signifikan dan tiga pengujian lainnya menunjukkan hasil yang tidak signifikan. Selanjutnya interaksi antara strategi pembelajaran dan kemampuan apresiasi seni musik dalam mempengaruhil belajar Seni Musik siswa ditunjukkan pada Gambar 1.

\section{Skor Rerata Seni Musik}

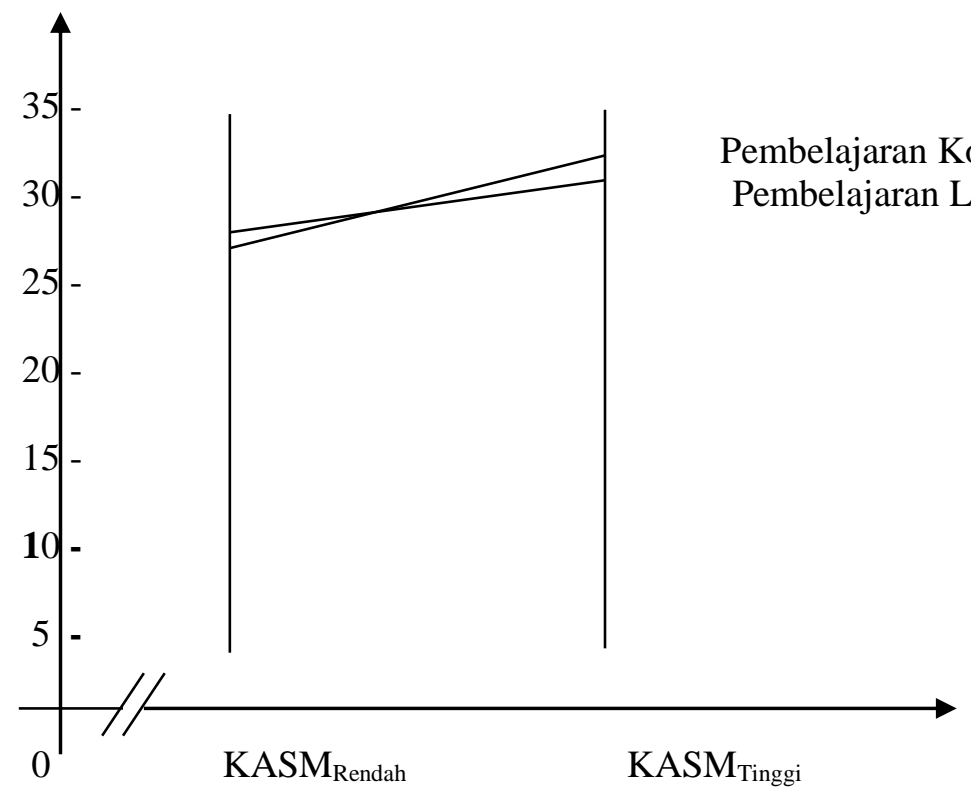

Gambar 1. Interaksi Strategi Pembelajaran Dan Kemampuan ApresiasiSeni Musik 


\section{Pembahasan}

Rerata hasil belajar Seni Musik siswa yang diajar dengan strategi pembelajaran konstruktivisme lebih tinggi daripada rata-rata hasil belajar Seni Musik siswa yang diajar dengan strategi pembelajaran langsung. Hal ini menunjukkan bahwa strategi pembelajaran konstruktivisme terbukti efektif dapat meningkatkan hasil belajar Seni Musik siswa secara keseluruhan baik untuk kelompok siswa yang memiliki kemampuan apresiasi seni musik tinggi maupun kelompok siswa yang memiliki kemampuan apresiasi seni musik rendah. Dengan demikian dapatlah dimaknai bahwa strategi pembelajaran konstruktivisme lebih efektif untuk meningkatkan hasil belajar Seni Musik tanpa memperhatikan kemampuan apresiasi seni musik siswa.

Hal ini dapat terjadi karena dalam pembelajaran yang menerapkan strategi pembelajaran konstruktivisme, siswa cenderung aktif untuk merekonstruksi sendiri ilmu yang akan diperolehnya, siswa berupaya menemukan dan menyelesaikan masalah dalam kerangka pencapaian tujuan pembelajaran. Di samping itu strategi pembelajaran konstruktivisme bertujuan menumbuhkan partisipasi siswa dalam memecahkan isu atau masalah yang diajukan oleh guru dalam pembelajaran, menumbuhkan diskusi di antara siswa dalam mencari penyebab dan solusi terhadap masalah tersebut. Oleh karena itu peran guru dalam strategi pembelajaran konstruktivisme lebih dominan sebagai fasilitator yang mengarahkan siswa untuk menemukan dan mengkonstruk sendiri pengetahuannya.

Pembelajaran konstruktivisme adalah strategi pembelajaran yang berorientasi pada aktivitas siswa dalam mengkonstruksi pengetahuannya melalui aktivitas belajar yang dilakukan siswa sebagaimana dijelaskan Slavin (2009) sebagai berikut: (1) memusatkan perhatian kepada berfikir atau proses mental anak, tidak sekedar kepada hasilnya dan (2) mengutamakan peran siswa dalam berinisiatif sendiri dan keterlibatan aktif dalam kegiatan belajar. Hal senada dijelaskan Muijs dan Reynolds (2008) menjelaskan bahwa pembelajaran konstruktivisme yaitu siswa mengkonstruksikan pengetahuan secara aktif dan tidak menerima begitu saja dari guru. Belajar adalah sebuah pencarian makna, dimana guru berperan mendorong siswa untuk mengkonstruksikan makna dengan menstrukturisasikan berbagai kegiatan di seputar ide-ide besar dan eksplorasi, memberi siswa cukup waktu untuk mengeksplorasi berbagai konsep secara seksama dan menghubungkan pengetahuan baru dengan apa yang sudah diketahui siswa.

Temuan penelitian ini mendukung penelitian sebelumnya yang dilakukan Sianturi (2008) dalam penelitiannya tentang Pengaruh Strategi Pembelajaran dan Locus of Control Terhadap Hasil Belajar Matematika Siswa Sekolah Menengah Pertama (SMP) Budi Murni I Medan yang menemukan proses pembelajaran dengan menerapkan strategi pembelajaran konstruktivisme memperlihatkan hasil belajar matematika siswa yang lebih tinggi dibandingkan dengan siswa yang mengikuti pembelajaran dengan strategi ekspositori.

Hasil penelitian ini juga mendukung hasil penelitian Widiastuti (2009) tentang Pengaruh Strategi Pembelajaran Dan Kemampuan Apresiasi Seni Musik Terhadap Hasil Belajar Harmoni Siswa Sekolah Menengah Kejuruan (SMK) Negeri 11 Medan, menemukan bahwa secara umum terdapat perbedaan hasil belajar Harmoni siswa yang mengikuti pembelajarann strategi konstruktivisme dengan strategi discovery.

Rata-rata hasil belajar Seni Musik siswa dengan kemampuan apresiasi seni musik tinggi secara keseluruhan baik yang diajar dengan strategi pembelajaran konstruktivisme dan strategi pembelajaran langsung lebih tinggi baik daripada rata-rata hasil belajar Seni Musik siswa dengan kemampuan apresiasi seni musik rendah. Hal ini menunjukkan bahwa perbedaan kemampuan apresiasi seni musik mempengaruhi perolehan hasil belajar Seni Musik siswa. Untuk itu peran guru dalam kegiatan pembelajaran adalah memperhatikan kemampuan apresiasi seni musik siswa sehingga strategi yang diterapkan dalam kegiatan pembelajaran sesuai dengan karakteristik kemampuan apresiasi seni musik siswa.

Temuan di atas membuktikan bahwa faktor karakteristik kemampuan apresiasi seni musik signifikan untuk membedakan hasil belajar Seni Musik siswa Secara khusus bagi siswa dengan kemampuan apresiasi seni musik rendah dalam kegiatan pembelajaran Seni Musik diberikan tugas-tugas yang lebih banyak sehingga dapat menutupi kelemahan terhadap penguasaan materi Seni Musik. Hal ini sejalan dengan ungkapan Nooryan (2008) bahwa apresiasi seni musik merupakan suatu proses sadar yang dilakukan seseorang dalam menghargai dan memahami karya seni musik. 
Penjelasan yang sama disampaikan Sutopo (1987) bahwa apresiasi seni musik merupakan proses kadar yang dilakukan oleh penghayat dalam menghadapi dan menghagai karya seni musik. Selanjutnya Smith (1971) menjelaskan bahwa apresiasi seni musik merupakan proses pengenalan nilai karya seni, untuk menghargainya dan menafsir makna yang terkandung didalamnya.

Temuan penelitian ini mendukung penelitian sebelumnya yang dilakukan Widiastuti (2009) tentang Pengaruh Strategi Pembelajaran Dan Kemampuan Apresiasi Seni Musik Terhadap Hasil Belajar Harmoni Siswa Sekolah Menengah Kejuruan (SMK) Negeri 11 Medan, menemukan bahwa siswa dengan kecenderungan kemampuan apresiasi seni musik tinggi memperoleh hasil belajar Harmoni yang lebih tinggi dibandingkan siswa dengan kecenderungan apresiasi seni musik rendah.

Selanjutnya terdapat interaksi antara strategi pembelajaran dan kemampuan apresiasi seni musik dalam mempengaruhi hasil belajar Seni Musik siswa. Apabila dilihat rata-rata hasil belajar Seni Musik pada kelompok siswa dengan kemampuan apresiasi seni musik tinggi dan diajar dengan strategi pembelajaran konstruktivisme lebih tinggi dibandingkan dengan rata-rata hasil belajar Seni Musik pada kelompok siswa dengan kemampuan apresiasi seni musik rendah dan diajar dengan strategi pembelajaran langsung. Kemudian rata-rata hasil belajar Seni Musik pada kelompok siswa yang memiliki kemampuan apresiasi seni musik rendah dan diajar dengan strategi pembelajaran konstruktivisme lebih rendah dibandingkan dengan rata-rata hasil belajar Seni Musik kelompok siswa yang memiliki kemampuan apresiasi seni musik rendah dan diajar dengan strategi pembelajaran langsung. Hal ini bermakna bahwa bagi kelompok siswa yang memiliki kemampuan apresiasi seni musik rendah lebih baik diajar dengan menggunakan strategi pembelajaran langsung dibandingkan dengan menggunakan strategi pembelajaran konstruktivisme. Dengan demikian dapatlah ditarik kesimpulan bahwa strategi pembelajaran dan kemampuan apresiasi seni musik signifikan mempengaruhi hasil belajar Seni Musik siswa.

Hasil uji lanjut dengan uji Tukey menunjukkan dari enam kombinasi pengujian rata-rata hasil belajar Seni Musik maka terdapat tiga pengujian yang menunjukkan hasil yang signifikan dan tiga pengujian lainnya menunjukkan hasil yang tidak signifikan. Kombinasi pengujian lanjut yang dilakukan yaitu: (1) rata-rata hasil belajar Seni Musik siswa yang diajar dengan strategi pembelajaran konstruktivisme yang memiliki kemampuan apresiasi seni musik tinggi lebih tinggi dibandingkan rata-rata hasil belajar Seni Musik siswa yang diajar dengan strategi pembelajaran langsung yang memiliki kemampuan apresiasi seni musik tinggi, (2) rata-rata hasil belajar Seni Musik siswa yang diajar dengan strategi pembelajaran konstruktivisme yang memiliki kemampuan apresiasi seni musik tinggi lebih tinggi dibandingkan dengan rata-rata hasil belajar Seni Musik siswa yang diajar dengan strategi pembelajaran konstruktivisme yang memiliki kemampuan apresiasi seni musik rendah, (3) rata-rata hasil belajar Seni Musik siswa yang diajar dengan strategi pembelajaran konstruktivisme yang memiliki kemampuan apresiasi seni musik tinggi lebih tinggi dari rata-rata hasil belajar Seni Musik siswa yang diajar dengan strategi pembelajaran langsung yang memiliki kemampuan apresiasi seni musik rendah, (4) rata-rata hasil belajar Seni Musik siswa yang diajar dengan strategi pembelajaran langsung yang memiliki kemampuan apresiasi seni musik tinggi lebih tinggi dari rata-rata hasil belajar Seni Musik siswa yang diajar dengan strategi pembelajaran konstruktivisme yang memiliki kemampuan apresiasi seni musik rendah, (5) rata-rata hasil belajar Seni Musik siswa yang diajar dengan strategi pembelajaran langsung yang memiliki kemampuan apresiasi seni musik tinggi lebih tinggi dari rata-rata hasil belajar Seni Musik siswa yang diajar dengan strategi pembelajaran langsung yang memiliki kemampuan apresiasi seni musik rendah, dan (6) rata-rata hasil belajar Seni Musik siswa yang diajar dengan strategi pembelajaran konstruktivisme yang memiliki kemampuan apresiasi seni musik rendah lebih rendah dari rata-rata hasil belajar Seni Musik siswa yang diajar dengan strategi pembelajaran langsung yang memiliki kemampuan apresiasi seni musik rendah..

Selanjutnya dalam pelaksanaan pembelajaran Seni Musik pada tingkat sekolah menengah pertama memiliki cakupan materi cukup padat. Memperhatikan hal tersebut, maka dibutuhkan suatu strategi pembelajaran yang mampu untuk mendeskripsikan dan memahami secara rinci konsep-konsep maupun penguasaan keterampilan secara fektif dan efesien. Dengan demikian siswa diharapkan mampu untuk membangun atau mengkonstruk sendiri pengetahuan dan ketrampilan yang dibutuhkan untuk memecahkan masalah-masalah 
belajarnya. Di samping itu siswa harus menemukan sendiri pengetahuan dan ketrampilan tesebut, dan bukan karena diberitahukan oleh guru. Siswa mampu belajar secara aktif dan mandiri dengan mengembangkan atau menggunakan gagasangagasan dalam menyelesaikan masalah pembelajaran, sehingga pengetahuan dan ketrampilan akan dapat diingat dan dipahami dalam memori jangka panjang, dan sewaktuwaktu dapat digunakan sesuai dengan kebutuhan belajar siswa.

Hal ini sejalan dengan ungkapan Gagne dan Briggs (1988) menjelaskan ada dua faktor atau kondisi yang mempengaruhi terjadinya peristiwa belajar yaitu faktor internal dan faktor eksternal. Faktor internal adalah: (1) pengetahuan faktual, yaitu apa yang telah diketahui seseorang, (2) kemampuan intelektual, kemampuan ini harus sesuatu yang telah dipelajari agar kecakapan itu dapat dimunculkan pada waktunya, (3) strategi belajar, seseorang memiliki berbagai strategi ketika berada dalam suatu situasi belajar yang berbeda. Keadaan internal ini merupakan prakondisi untuk keberhasilan pembelajaran.

\section{PENUTUP}

Simpulan

Pertama, rata-rata hasil belajar Seni Musik siswa yang diajar dengan strategi pembelajaran konstruktivisme lebih tinggi dibandingkan dengan rata-rata hasil belajar Seni Musik siswa yang diajar dengan strategi pembelajaran langsung. Dengan demikian strategi pembelajaran konstruktivisme lebih efektif diterapkan dalam pembelajaran Seni Musik guna meningkatkan hasil belajar Seni Musik siswa.

Kedua, rata-rata hasil belajar Seni Musik siswa yang memiliki kemampuan apresiasi seni musik tinggi yang diajar dengan strategi pembelajaran konstruktivisme maupun strategi pembelajaran langsung lebih tinggi dibandingkan dengan rata-rata hasil belajar Seni Musik siswa yang memiliki kemampuan apresiasi seni musik rendah.

Ketiga, terdapat perbedaan pengaruh strategi pembelajaran dan kemampuan apresiasi seni musik yaitu untuk siswa yang memiliki kemampuan apresiasi seni musik tinggi lebih tepat diajar dengan strategi pembelajaran konstruktivisme daripada diajar dengan strategi pembelajaran langsung, sedangkan siswa yang memiliki kemampuan apresiasi seni musik rendah lebih tepat diajar dengan strategi pembelajaran langsung daripada diajar dengan strategi pembelajaran konstrukrtivisme.

\section{Saran}

Dari hasil temuan-temuan penelitian sebelumnya maka dapatlah disampaikan beberapa saran sebagai berikut:

1. Kepada guru agar dapat menetapkan pilihan strategi pembelajaran yang lebih sesuai dengan karakteristik siswa, khusus pada pelajaran Seni Musik, guru memperhatikan kemampuan apresiasi seni musik.

2. Kepada peneliti lain disarankan untuk meneliti karakteristik siswa yang turut mempengaruh pencapaian hasil belajar di luar kemampuan apresiasi seni musik.

3. Kepada penelti lain, agar dapat dapat meneliti dalam ranah Bloom yang berbeda dengan pengukuran yang dilakukan dalam penelitian sehingga tercapai pengetahuan yang lebih komprehensif.

\section{DAFTAR PUSTAKA}

Badiran, M. (2006). Pengembangan Model Pembelajaran Seni Rupa. Medan: Jurnal Tabularasa Pascasarjana Unimed

Badiran, M. Sibuea, A.M dan Yusri. (2008). Pengembangan Model Pembelajaran Seni Rupa Sebagai Upaya Meningkatkan Mutu Belajar Mengajar Seni Rupa. Jurnal Teknologi Pendidikan. Medan: Pascasarjana Unimed.

Bahari, Y. (2005). Pengaruh Strategi Pembelajaran Kooperatif Dan Kreatvitas Siswa Terhadap Hasil Belajar Matematika Siswa MIN Medan. Tesis. Medan: Unimed

Dick, W. and Carey, L. (1996). The Systematic Design of Instruction. Fouth Edition. New York: Harper Collin College Publisher

Departemen Pendidikan Nasional. (2006). Standar Kompetensi dan Kompetensi dasar Mata Pelajaran Seni Musik SMP. Jakarta: Direktorat Jenderal Manajemen Pendidikan Dasar Dan Menengah

DePorter, B. dan Hernacki, M. (2003). Quantum Learning, Unleashing The Genius In You. Penerjemah: Alwiyah Abdurrahman. Quantum Learning Membiasakan Belajar Nyaman dan Menyenangkan. Bandung: Kaifa

DePorter, B., Reardon, M., dan Nourie. S.S. (2003). Quantum Teaching, Orchestrating Student Succes. Penerjemah: Ary Nilandari. Quantum 


\section{Teaching Mempraktikkan Quantum Learning Di Ruang-Ruang Kelas. Bandung: Kaifa}

Gagne, R. M. (1977). The Condition Of Leaining, Third Edition, New York: Holt, Rinehart and Winston.

Gredler, M.E.B. (1994). Learning and Instruction Theory Into Practice, Belajar dan Membelajarkan. Penerjemah: Munandir. Jakarta: Raja Grafindo Persada

Gulo, W. (2008). Strategi Belajar Mengajar. Jakarta: Grasindo

Hamid, K. (2007). Teori Belajar dan Pembelajaran. Medan: Pascasarjana Unimed

Hergenhahn, B.R dan Olson, M.H. (2008). Theories of Learning. Penerjemah: Tri Wibowo B.S. Teori Belajar. Jakarta: Kencana Prenada Media Group

Joyce, B. Weil, M.dan Calhoun, E. (2009). Models of Teaching, Penerjemah: Achmad Fawaid dan Ateila Mirza. Model-Model Pengajaran. Yogyakarta: Pustaka Pelajar

Kemp, J.E. (1994). The Instructional Design Process. Penerjemah: Asril Mardjohan Proses Perancangan Pengajaran. Bandung: ITB

Merril, M.D dan Twitchel D.G. (1994). Instructional Design Theory. New Jersey; Englewood Cliffs

Muijs, D. dan Reynold D. (2008). Effective Teaching. Penerjemah: Helly Prajitno Soetjipto dan Sri Mulyanti Soetjipto. Effective Teaching Teori dan Aplikasi. Yogyakarta: Pustaka Pelajar

Nooryan, B. (2008). Kritik Seni. Yogyakart: Pustaka Pelajar

Romizowski, AZ. (1981). Designing Instructional System. New York: Nichol Publishing Company
Sanjaya, W. (2007). Strategi Pembelajaran Berorientasi Standar Proses Pendidikan. Jakarta: Kencana Prenada Media Group.

Santrock, J.W. (2007). Educational Psychology $2^{\text {nd }}$ Edition. Penerjemah: Tri Wibowo B.S. Psikologi Pendidikan. Jakarta: Kencana Predana Media Group

Sianturi, R. (2008). Pengaruh Strategi Pembelajaran Dan Locus of Control Terhadap Hasil Belajar Matematika Siswa Sekolah Menengah Pertama (SMP) Budi Murni I Medan. Tesis. Medan: Unimed.

Slavin, R.E. (2009). Educational Psychology, Theor $y$ and Practice. Eight Edition. Penerjemah:

Smith, B.O. (1971). Aesthetic and Criticism in Art Education. Chicago,IL: Rand McN ally and Company

Sudjana, N. (2002). Dasar-Dasar Proses Belajar Mengajar. Bandung: Sinar Baru Algensindo

Trianto. (2009). Mendesain Model Pembelajaran Inovatif Progresif. Jakarta: Kencana Prenada Media Group.

Widiastuti, U. (2009). Pengaruh Strategi Pembelajaran Dan Kemampuan Apresiasi Seni Musik Terhadap Hasil Belajar Harmoni Siswa Sekolah Menengah Kejuruan (SMK) Negeri 11 Medan. Tesis. Medan: Unimed

Woolfolk. A.E. (2009). Educational Psychology Active Learning Edition. Penerjemah: Helly Prajitno Soetjipto dan Sri Mulyanti Soetjipto. Psikologi Pendidikan. Buku I. Yogyakarta: Pustaka Pelajar

Zahorik, John. A. (1995). Constructivist Teaching and Learning. Indiana; Phi Delta Kappa Educational Foundation 